International Journal of Community and Cooperative Studies

Vol.8 No.1, pp.9-22, June 2020

Published by ECRTD- UK

ISSN 2057-2611(Print),

ISSN 2057-262X (Online)

\title{
THE RELATIONSHIP BETWEEN MEMBER FINANCIAL LITERACY AND LOAN REPAYMENT IN SAVINGS AND CREDIT CO-OPERATIVE SOCIETIES IN UASIN-GISHU COUNTY, KENYA
}

\author{
Wilson K. Metto \\ The Co-operative University of Kenya (CUK), \\ mettowilson@yahoo.com
}

\begin{abstract}
Financial literacy is the possession of knowledge, skills and attitudes that enable an individual to use money effectively by making sound informed financial decisions, it plays a critical role in Savings and Credit Co-operative Societies (SACCOS). SACCOS are vital financial institutions that encourage thrift to give loans to members; however, Loan Repayment (LR) poses a threat to SACCOS' sustainability. The main objective of this study was to examine the relationship between Member Financial Literacy (MFL) and LR in SACCOS. Specifically, the study - (i) assessed the MFL in SACCOS (ii) determined the influence of MFL in SACCOS on LR. The study adopted cross-sectional research design whereby 384 members and 147 SACCOS were drawn using simple random sampling techniques. A survey, in-depth interview and Focus Group Discussions (FGDs) were data collection methods. Binary logistic regression was used to analyse quantitative data while qualitative data were analysed using content analysis technique. Results revealed that MFL in SACCOS were low. The MFL were on budgeting, savings, debt management, and bookkeeping. Other indicators of MFL were financial capability, awareness and goal. Attitudes, beliefs and perceived power shaped financial behavior increasing the chances of member LR. The study concludes that MFL was crucial on determining LR. It recommends SACCOS' board members and managers to provide education on MFL in SACCOS before disbursing any loan and after to improve $L R$.
\end{abstract}

KEYWORDS: member financial literacy, loan repayment

\section{INTRODUCTION}

Savings and Credit Co-operative Societies (SACCOS) are forms of co-operatives offering financial services in form of loans, they have an estimated over $\$ 1.2$ trillion loans; but Loan Repayment (LR) poses a threat (WOCCU, 2017). SACCOS improve members' financial knowledge through education on Member Financial Literacy (MFL). A World Bank (2018) report acknowledges financial literacy as a global life skill important on financial decision-making. World Bank (2018) survey as cited by Demertzis and Batsaikhan (2018) rates financial literacy in United States at 57\%, Europe 50\%, Africa $33 \%$, Asia 28\%, Tanzania $40 \%$ and Kenya $38 \%$. 
Vol.8 No.1, pp.9-22, June 2020

Published by ECRTD- UK

ISSN 2057-2611(Print),

ISSN 2057-262X (Online)

The fifth Co-operative Principle requires SACCOS to promote Co-operative Education (CE) to overcome LR challenges. LR difficulties in co-operatives is worldwide, Countries with Credit Unions that are the same as SACCOS such as Argentina, Chile, Brazil, India and Uruguay are equally affected (Musabwasoni et al., 2018; Ng'ondi, 2013). Peoples' inadequate financial skills lead to wrong financial choices resulting to poor LR (Singh and Garg, 2018).

Financial literacy is defined as the skills, attitudes and behavior on how to make financial choices to optimize money use (Fernandes and Netemeyer, 2014). Financial skill is the ability to budget, save, manage debt and do bookkeeping decisive on member LR; they are influenced by financial attitudes. Financial attitudes are beliefs and values influencing behaviors like self-control, planning and making sound financial choices. Financial attitudes indicators were financial capability, awareness and goals. Financial awareness is knowledge about money, it transforms to a financial ability or capability and goals imperative to LR.

\section{LITERATURE REVIEW AND THEORETICAL UNDERPINNING}

Many SACCOS in Africa such as Ghana, Kenya and Tanzania experienced problems collecting back borrowed loans making it necessary to re-examine MFL (Mmari and Thinyane, 2019; Tehran et al., 2014). A study in Ghana by Yeboah and Oduro (2018) indicates that in Credit Unions loan default was a big concern. In Tanzania; Ministry of Agriculture, Food, Security and Co-operatives report indicates that out of 5424 registered SACCOS, only 1346 (25\%) were active (Ndiege et al., 2016). Further, TCDC (2018) report indicates that Tanzania shillings 1 299. 66 billion were issued as loans and 490.33 billion $(37 \%)$ was still outstanding.

Kenyan SACCOS contributes $45 \%$ of the Gross Domestic Product (GDP); Kenyan Vision 2030 Policy aims at using SACCOS to achieve economic development, however LR is a threat (MITCD, 2017). Efforts to improve LR including starting co-operative education day, enhancing education and credit committee's trainings have bore no fruits as LR problem persists. In deposit taking SACCOS; it rose from 5.23\% in 2016 to $6.14 \%$ in 2017 and $6.30 \%$ in 2018 as shown on Table 1.

Table 1: Trends of Un-Repaid Loans in SACCOS in Kenya

\begin{tabular}{llll}
\hline Year & 2016 & 2017 & 2018 \\
\hline $\begin{array}{l}\text { Loans in Billion Kenya } \\
\text { Shillings }\end{array}$ & 297.6 & 331.21 & 374.28 \\
Un-repaid loan in $(\%)$ & 5.23 & 6.14 & 6.30 \\
\hline
\end{tabular}

Source: The SACCO Societies Regulatory Authority (SASRA) Report- 2018 
Vol.8 No.1, pp.9-22, June 2020

Published by ECRTD- UK

ISSN 2057-2611(Print),

ISSN 2057-262X (Online)

Several studies including Abiodun and Harry (2016); Wanjiku and Muturi (2017) have examined the effect of employee financial literacy on Small Micro- Enterprises (SMEs). The studies found a relationship between financial literacy and performance. However, these studies were inconclusive, as they did not give clear information on the link between members and LR in SACCOS. This study aimed to examine the relationship between MFL and LR in SACCOS. Specifically, the study - (i) assessed the MFL in SACCOS (ii) determined the influence of MFL in SACCOS on LR. Literature reviewed shows that LR is an outcome of many factors such as job loss or business failure but this study has focused on MFL.

The theory of planned behavior by Ajzen (2012) was used. The theory states that beliefs, attitudes and perceived power shaped individuals' behavior and control actions. Perceived power is the presence of factors that impede or hinder a behavior. Co-operatives believe in values and ethics like self-responsibility and honesty, co-operative education prevent negative behavior that was in line with the theory. Conceptual framework on Figure 1 shows how MFL indicators such as financial budgeting, savings, financial awareness and goal were operationalised to affect timely LR. Co-operative bylaws, Act and the fifth Cooperative Principle moderates MFL skills.

\section{Independent Variable (MFL) Skills Intervening Variables Dependent Variable}

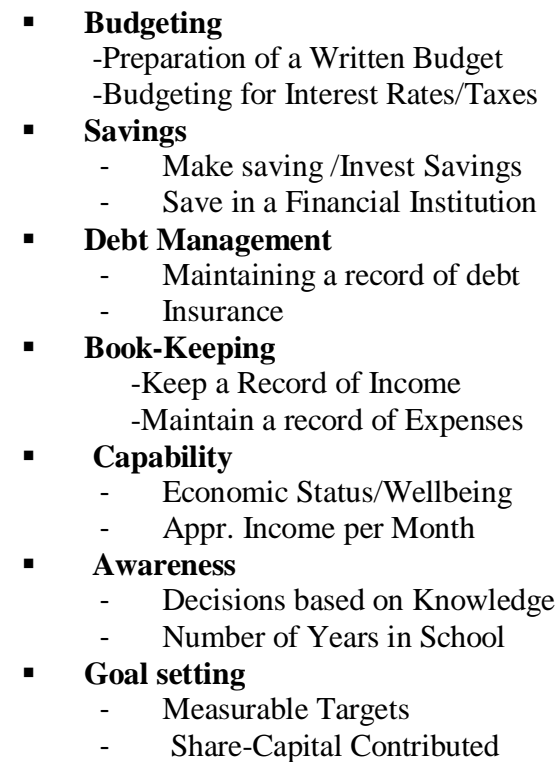

Figure1. Conceptual Framework, Key: Independent Variable Influen $\longrightarrow$ Intervening Variable Influence 
Vol.8 No.1, pp.9-22, June 2020

Published by ECRTD- UK

ISSN 2057-2611(Print),

ISSN 2057-262X (Online)

\section{METHODOLOGY}

The study was conducted in Uasin-Gishu County one of the 47 Counties in Kenya, located in the Northern part of the Rift Valley. Statistics at the Ministry of Industry Trade and Cooperative Development (MITCD), Uasin-Gishu County indicated that there were 238 SACCOS as at June 2018 operating in different capacities mostly in agricultural and business. The popularity of the County in agricultural and business activities had led to increase in the number of SACCOS that was good to explore. The choice of the County was because from the records, LR was a challenge affecting most SACCOS in Uasin-Gishu County (MITCD, 2017).

Cross-sectional research design was used whereby data collections were done once to establish the pattern of variables. This design was chosen because it enabled data collections at a single point in time and facilitate consideration of several characteristics of the variable at once (Rukwaru, 2015; Flick, 2011). The unit of analysis was the members of SACCOS; financial literacy was an independent variable while LR was a dependent variable. To get members' sample size, Cochran (1977) formula for infinite population was employed such that:

$$
n_{0}=\frac{z^{2} p q}{e^{2}}
$$

Where $n_{0}=$ sample size, $\mathrm{Z}$ is the selected critical value, $\mathrm{p}$ estimated proportion of attribute, $\mathrm{q}=1-\mathrm{p}$, e level of precision. Assuming $\mathrm{p}=0.5$, taking confidence level as $\pm 0.5, \mathrm{p}=0.5, \mathrm{q}=1$ $0.5=0.5, \mathrm{e}=0.05, \mathrm{z}=1.96$

$$
n_{0}=\frac{(1.96)^{2}(0.5)(0.5)}{(0.05)^{2}}=384.16=384 \text { members }
$$

For the sampled SACCOS, they were obtained using Mugenda and Mugenda formula, which states that if the total population is more than 30, then a sample size of $10 \%$ may be taken, therefore out of 238 SACCOS, 24 were sampled. There were six Sub-Counties in Uasin-Gishu County; therefore, four SACCOS were picked per Sub-County. Urban SACCOS were about three times more than Rural SACCOS, thus the study took ratio 3:1 of Urban to Rural SACCOS per Sub-County. 
Vol.8 No.1, pp.9-22, June 2020

Published by ECRTD- UK

ISSN 2057-2611(Print),

ISSN 2057-262X (Online)

Table 2: Sampled SACCOS and Members

\begin{tabular}{lllll}
\hline Sub-County & \multicolumn{2}{c}{ Type of SACCO } & Sampled & Sampled \\
& Urban SACCOS & Rural SACCOS & SACCOS & Members \\
\hline 1.Kapseret & 3 & 1 & 4 & 64 \\
2.Turbo & 3 & 1 & 4 & 64 \\
3.Kesses & 3 & 1 & 4 & 64 \\
4.Moiben & 3 & 1 & 4 & 64 \\
5.Soy & 3 & 1 & 4 & 64 \\
6.Ainabkoi & 3 & 1 & 4 & 64 \\
Total & 18 & 6 & 24 & 384 \\
\hline
\end{tabular}

After determining the sample size of 384 members and 24 SACCOS, simple random sampling technique was used to pick 16 members per SACCOS because it avoided bias and accorded all members equal chances. For the SACCOS, a purposive sampling technique was used in selection of Urban and Rural SACCOS.

The key informants included County Co-operative Officers, board members, managers and co-operative trainers such as The Co-operative University of Kenya. Both quantitative and qualitative data were collected using questionnaire, key informants interview and Focus Group Discussions (FGDs) respectively. For FGDs, three different groups consisting of eight members being-County Co-operative Officers, managers and committee representatives and members were selected using simple random sampling techniques.

To remove ambiguities and vagueness on the instruments; reliability test was carried out in the neighboring County, Nandi at Nandi- Hills Ukulima SACCOS, Boresha SACCOS, Nandi Youth Bunge SACCOS and MITCD- Nandi County whereby 10\% of the total sample size that were 39 members were engaged. Variables, which could have influenced the dependent variable, were isolated and controlled using research design, hence guaranteeing results the possibility of use to generalize. Cronbachs' co-efficient of reliability on internal consistency was 0.815 , implying that it was greater than 0.70 hence, reliable. The study measurements criterion validity was ascertained by ensuring that instruments exhaustively captured all vital aspects and one-measure results corresponded with another respectively as stated by (Rukwaru, 2015).

The quantitative data were analyzed using descriptive and inferential statistics. Inferentially, binary logistic regression was used because LR was dichotomous; a member could do timely LR or fail. Measurements of the independent variables involved seven determinants obtained from literature review hypothesized to predict timely LR in SACCOS. Budgeting $\mathrm{X}_{1}$, savings $\mathrm{X}_{2}$, debt management $\mathrm{X}_{3}$ and bookkeeping skills $\mathrm{X}_{4}$ were the independent variables. Other independent variables were financial capability $\mathrm{X}_{5}$, 
Vol.8 No.1, pp.9-22, June 2020

Published by ECRTD- UK

ISSN 2057-2611(Print),

ISSN 2057-262X (Online)

financial awareness $\mathrm{X}_{6}$ and financial goal $\mathrm{X}_{7}$. Hosmer (1989) binary logistic model applied was as follows-

$\pi(\tilde{\mathrm{x}})=\log \left[\frac{\pi(\tilde{\mathrm{x}})}{1-\pi(\tilde{\mathrm{x}})}\right]=\beta_{0}+\beta_{1} \mathrm{x}_{1}+\beta_{2} \mathrm{x}_{2}+\ldots+\beta_{\mathrm{p}} \mathrm{x}_{\mathrm{p}}+\mathrm{e}$

Where $\pi(\tilde{\mathrm{x}})=\log \left[\frac{\pi(\tilde{x})}{1-\pi(\tilde{x})}\right]=\mathrm{Y}$, the probability of LR indicated was binary measured by one for LR and zero for otherwise, $\beta_{0^{-}}$was constant term, $\beta_{1^{-}} \beta_{\mathrm{p}^{-}}$was coefficients of regression and e error term. For qualitative analysis, data from interviews on key informants was transcribed, coded and classified into themes, it was then analysed based on the content within the thematic areas. This information complimented quantitative data. The measurement levels for quantitative data were-

\begin{tabular}{|c|c|c|c|}
\hline \multicolumn{2}{|c|}{ Variables } & \multirow{2}{*}{$\begin{array}{l}\text { Measurements } \\
1 \text { if a member makes a budget and } 0 \text { for } \\
\text { otherwise }\end{array}$} & \multirow{2}{*}{$\begin{array}{l}\text { Type of } \\
\text { Variable } \\
\text { Predictor }\end{array}$} \\
\hline MFL- & Budgeting - $\mathrm{X}_{1}$ & & \\
\hline \multirow[t]{6}{*}{ Skills } & Savings $-\mathrm{X}_{2}$ & Amount saved in SACCOS & \\
\hline & $\begin{array}{l}\text { Debt Management } \\
-\mathrm{X}_{3}\end{array}$ & $\begin{array}{l}\text { Number of trainings on debt } \\
\text { management attended }\end{array}$ & \\
\hline & Bookkeeping $-\mathrm{X}_{4}$ & $\begin{array}{l}\text { Number of trainings on book-keeping } \\
\text { attended }\end{array}$ & \\
\hline & $\begin{array}{l}\text { Finan. Capability } \\
\mathrm{X}_{5}\end{array}$ & Approximated income per month & \\
\hline & $\begin{array}{l}\text { Finan. Awareness } \\
-\mathrm{X}_{6}\end{array}$ & Number of years in school & \\
\hline & $\begin{array}{l}\text { Finan. Goal- } \mathrm{X}_{7} \\
\text { Loan Repayment }\end{array}$ & $\begin{array}{l}\text { Members' share-capital } \\
1 \text { if repaying a loan and } 0 \text { for otherwise }\end{array}$ & Dependent \\
\hline
\end{tabular}

Table 3: Independent and Dependent Variables Measurement Levels

\section{RESULTS AND DISCUSSIONS}

The aim of this study was to examine the relationship between MFL in SACCOS and LR; this was in the light of dwindling LR in SACCOS. Financial literacy variable was tested on LR because literature reviewed (Lusardi, 2019; World Bank, 2018; Wanjiku and Muturi, 2017) hints at a possibility of a relationship between the two. From this objective, the study tested the hypotheses that - (i) There is no significant relationship between MFL and LR in SACCOS, $\mathrm{H}_{0}=$ or $>$ than 0.05 ; and (ii) There is a positive significant relationship between MFL and LR in SACCOS, $\mathrm{H}_{\mathrm{A}}=<$ than 0.05 .

The study examined the respondents' social demographic characteristics in order to understand the source of information and link to the objectives. More than half of the respondents $(61 \%)$ were male while $(39 \%)$ were female. For the respondents' ages, those who were between $45-54$ years were less than a half $(41 \%)$; 35-44 years were a quarter 
Vol.8 No.1, pp.9-22, June 2020

Published by ECRTD- UK

ISSN 2057-2611(Print),

ISSN 2057-262X (Online)

(25\%). Less than a half $(41 \%)$ of the respondents were with tertiary education, members with secondary education were $(39 \%)$ while the rest of the members were having primary education and below. The types of SACCOS engaged were:- Rural SACCOS $25 \%$ and Urban SACCOS $75 \%$.

Table 4: Members' Social-Demographic Characteristics ( $N=384)$

\begin{tabular}{lccc}
\hline & Members $(\mathrm{N}=384)$ & $\begin{array}{c}\text { Frequency } \\
(\%)\end{array}$ & Cumulative (\%) \\
\hline Sex & 150 & 39 & 39 \\
Female & 234 & 61 & 100 \\
Male & & & \\
Age & 40 & 10 & 10 \\
$18-25$ years & 47 & 12 & 22 \\
$26-34$ years & 96 & 25 & 87 \\
$35-44$ years & 156 & 41 & 100 \\
$45-54$ years & 45 & 12 & 7 \\
$55+$ years & & 7 & 20 \\
Educational & 27 & 13 & 59 \\
Non-educated & 50 & 39 & 100 \\
$\begin{array}{l}\text { Primary } \\
\text { education }\end{array}$ & & 41 & \\
Secondary edu. & 150 & & \\
Tertiary & 157 & & \\
education & & & \\
\hline
\end{tabular}

The findings on Table 5 indicate that (38\%) of the members were having budgeting skills. This implies that these members' money was controlled by spending plans, which promotes self-control financial behavior, patience and financial stability increasing the probability of member LR. These finding confirms the World Bank (2018) report indicating the low financial literacy among people that was (38\%) in Kenya. Kinyuira (2017) study on the impact of co-operative education and training on performance observed that most SACCOS were not providing co-operative education to members likely to affect SACCOS' activities. Co-operative education is important because it enlightened members on financial attribute budgeting and related co-operative ethics such as honest and self-responsibility significant to LR.

For debt management, (32\%) had the skill; this suggests that members were aware about the importance of debt management; however, more education on financial literacy was likely to improve it as indicated by (Lusardi and Tufano, 2015). Members with saving culture were also $32 \%$, this implies that although savings were SACCOS' loaning power, 
Vol.8 No.1, pp.9-22, June 2020

Published by ECRTD- UK

ISSN 2057-2611(Print),

ISSN 2057-262X (Online)

most of the members were not keen to save. This finding adds knowledge to (Mmari et $a l ., 2019$ ) study on financial performance of SACCOS in Lesotho that stated that SACCOS members were not making adequate savings inhibiting member LR capability. Members with bookkeeping skills were only $31 \%$.

This meant that most members were having no written plan of expenditure confirming Lusardi (2019) finding that people without a record of expenses were risking financial instability due to over spending. On financial capability, it was 30\%; financial awareness was $29 \%$ while financial goal was $28 \%$. The implication of the finding is that the members had these abilities, which explains the World Bank (2018) survey that indicated that people were financially literate but required frequent education as a reminder.

Table 5: Member Financial Literacy Status in SACCOS

\begin{tabular}{lccc}
\hline Variable & $\begin{array}{l}\text { Total } \\
\text { Members(N) }\end{array}$ & $\begin{array}{l}\text { Number of Members ( } \\
\text { n) }\end{array}$ & Percentage (\%) \\
Budgeting & 384 & 146 & 38 \\
Debt & 384 & 123 & 32 \\
Management & & & \\
Savings & 384 & 122 & 32 \\
Bookkeeping & 384 & 120 & 31 \\
Capability & 384 & 116 & 30 \\
Awareness & 384 & 112 & 29 \\
Goals & 384 & 108 & 28 \\
\hline
\end{tabular}

The findings on LR on Table 6 indicate that out of the 384 members sampled, $56 \%$ were between excellent and good, meaning those who were excellent were making timely LR, the members that were good at times had minor cases of default. This result confirms the high rate of defaulted loans in SACCOS as found by Mutegi et al. (2015) in a study on financial literacy and LR. Soni and Saluja (2018) opined that more member enlightenment was required in SACCOS for members to learn the importance of their roles and responsibilities, implicit is self-responsibility.

The members who were not repaying loan were $44 \%$. The implication of Soni and Saluja (2018) finding fits the theory of planned behavior by Ajzen (2012) on perceived power and behavior change. Perceived power is a measure taken to hinder occurrence of a behavior like loan default. Further, it suggests that loan default was a behavioral problem in SACCOS calling for urgent intervention. 


\section{Table 6: Members Loan Repayment Status in SACCOS}

\begin{tabular}{lllccc}
\hline Members N=384 & \multicolumn{4}{c}{ Loan Repayment Status } \\
& Excellent & Good & Poor & Very & Per (\%) \\
& & & & Poor & \\
\hline 156 & $\sqrt{n}$ & $\sqrt{ }$ & & & 56 \\
59 & & & $\sqrt{ }$ & & 44 \\
50 & & & & $\sqrt{ }$ & \\
\hline
\end{tabular}

Records from Uasin-Gishu County Co-operative Enterprises Development Office shows that the County Government of Uasin-Gishu; loaned SACCOS members through 132 SACCOS as shown on Table 7. The amount is in Kenya Shillings in (millions); in 2014, 120 million Kenya Shillings was disbursed and Kenya shillings 41 million were defaulted represented by $34.2 \%$, this means that members were lacking the skills to use and returned money. Wanjiku and Mutari (2017) study on financial performance of employees in church confirms that employees who were budgeting always had enough money for other tasks positively affecting LR status.

Wanjiku and Mutari (2017) finding was contradicted by Kumbhat (2016) study which stated that continuous member enlightening on co-operative values and ethics such as selfresponsibility and honest increases the probability of Credit Unions success on LR. In 2015 out of Kenya Shillings 250 million given out 107.5 were defaulted indicated by $43 \%$, this implied that there were a rising loan default trend. The defaulted loan in 2016 was $45 \%$ and for 2017 , it was $47 \%$. About 2018, defaulted loan was $49 \%$. The finding suggests that SACCOS' members encounter difficulties repaying loan and therefore re-examining MFL was a necessity.

Table 7: Uasin-Gishu County Funds Loaned To Members Through SACCOS in (Million Ksh.)

\begin{tabular}{llllll}
\hline Loan (N=132) & 2014 & 2015 & 2016 & 2017 & 2018 \\
\hline Disbursed Loan & 120 & 250 & 435 & 302 & 564 \\
Loan Repaid & 79 & 142.5 & 239.5 & 160.1 & 290.4 \\
Un Repaid Loan & 41 & 107.5 & 195.5 & 141.9 & 273.6 \\
Percentage (\%) of Un-Repaid & 34.2 & 43.0 & 44.9 & 47.0 & 48.5 \\
Loan & & & & & \\
Number of Education on MFL & 148 & 142 & 157 & 145 & 162 \\
\hline
\end{tabular}

Source-Uasin Gishu County Co-operative Office-Risk Management-Department

\section{The Implications}

The implications of MFL on LR were obtained by running the binary logistic model whereby the probability of timely LR was one and zero for otherwise, the results were 
shown on Table 9. From the model $\pi(\tilde{\mathrm{x}})=\log \left[\frac{\pi(\tilde{\mathrm{x}})}{1-\pi(\tilde{\mathrm{x}})}\right]=\beta_{0}+\beta_{1} \mathrm{x}_{1}+\beta_{2} \mathrm{x}_{2}+\ldots+\beta_{\mathrm{p}} \mathrm{x}_{\mathrm{p}} \ldots$

$$
\begin{gathered}
\pi(\tilde{\mathrm{x}})=\log \left[\frac{\pi(\tilde{\mathrm{x}})}{1-\pi(\tilde{\mathrm{x}})}\right]=2.298-1.862 \mathrm{x}_{1}-1.900 \mathrm{x}_{2}+1.033 \mathrm{x}_{3}+0.902 \mathrm{x}_{4}+0.340 \mathrm{x}_{5}+1.843 \mathrm{x}_{6} \\
+0.332 \mathrm{x}_{7}
\end{gathered}
$$

Where $\log \left[\frac{\pi(\tilde{x})}{1-\pi(\tilde{x})}\right]=\mathrm{Y}$ was the probability that a member will do timely LR . The odds was $\log \left[\frac{\pi(\tilde{x})}{1-\pi(\tilde{x})}\right]$, therefore, prediction was on the probability of increase or decrease on the $\log$ of odds of $\pi(\tilde{\mathrm{x}})$. From the model, when $\mathrm{X}_{1}, \mathrm{X}_{2}, \mathrm{X}_{3}, \mathrm{X}_{4}, \mathrm{X}_{5}, \mathrm{X}_{6}$ and $\mathrm{X}_{7}$ equals to zero, log odds of $Y$ was 2.298, meaning that if other variables were held constant, member budgeting , savings, debt management ,bookkeeping, capability, awareness and goal decreases the probability of a member not repaying loan by 2.298 times. This suggests that to address LR, it was necessary for members to have these skills. Exponential B indicates that all these variables predicted LR by 9.040. From the model results on Table 9, a unit increase on budgeting, savings and debt management decreases the odds of a member not repaying a loan by $(-1.862),(-1.900)$ and (1.033) respectively. Again, a unit increase on financial awareness and bookkeeping decreases the odds of LR by (1.834 and (0.902) compared to (0.304) and (0.332) for financial capability and goal.

\begin{tabular}{|c|c|c|c|c|c|c|c|}
\hline \multirow[t]{2}{*}{ Variable } & \multirow[t]{2}{*}{ B } & \multirow[t]{2}{*}{ S.E. } & \multirow[t]{2}{*}{ Wald } & \multirow[t]{2}{*}{$\mathrm{p}$} & \multirow[t]{2}{*}{$\begin{array}{c}\operatorname{Exp}(B \\
)\end{array}$} & \multicolumn{2}{|c|}{$\begin{array}{l}\text { 95\% C.I.for } \\
\text { EXP(B) }\end{array}$} \\
\hline & & & & & & Lower & Upper \\
\hline Constant & 2.298 & 0.326 & 7.008 & 0.000 & 9.040 & & \\
\hline $\begin{array}{l}\text { Budgeting } \\
\mathrm{X}_{1}\end{array}$ & -1.862 & 0.344 & 33.922 & $0.000 *$ & 1.196 & 2.409 & 4.240 \\
\hline $\begin{array}{l}\text { Savings } \\
\mathrm{X}_{2}\end{array}$ & -1.900 & 0.350 & 15.058 & $0.000^{*}$ & 2.000 & 1.000 & 1.001 \\
\hline $\begin{array}{l}\text { Debt Man. } \\
\mathrm{X}_{3}\end{array}$ & 1.033 & 0.307 & 24.746 & $0.000^{*}$ & 1.067 & 0.955 & 0.980 \\
\hline $\begin{array}{l}\text { Bookkeeping } \\
\mathrm{X}_{4}\end{array}$ & 0.902 & 0.207 & 21.458 & $0.031 *$ & 1.000 & 0.877 & 0.987 \\
\hline $\begin{array}{l}\text { Capability } \\
\mathrm{X}_{5}\end{array}$ & 0.340 & 0.087 & 11.340 & 0.451 & 0.507 & 0.459 & 0.567 \\
\hline $\begin{array}{l}\text { Awareness } \\
\mathrm{X}_{6}\end{array}$ & 1.834 & 0.398 & 33.876 & $0.001 *$ & 1.186 & 2.398 & 4.140 \\
\hline $\begin{array}{l}\text { Goal } \\
7\end{array}$ & 0.332 & 0.245 & 10.870 & 0.464 & 0.502 & 0.359 & 0.478 \\
\hline
\end{tabular}

Table 9: Relationship between MFL and LR

\section{*Significant at $\mathbf{P}<0.05$}


Vol.8 No.1, pp.9-22, June 2020

Published by ECRTD- UK

ISSN 2057-2611(Print),

ISSN 2057-262X (Online)

The $\mathrm{p}$ values for all predictor variables were less than 0.05 implying a positive significant relationship with LR except for financial capability and goal. Cox and Snell was 0.421 and Nagelkerke R was 0.544 , this indicates that the model predicted between (42 and 54\%) of the results, $-2 \log$ likelihood was 274.865. Hosmer and Lemeshow test $\mathrm{p}$ value was 0.000 , on the classification Table, the overall percentage was (81.5). This shows that the model predicted correctly $81.5 \%$ of the results. Pearsons' correlation as indicated by the Omnibus test shows that all the variables on the model fitted well the model and were statistically significant; chi-square was (251.949, significant at 0.000). From these results, null hypotheses $\left(\mathrm{H}_{0}\right)$ that stated that there is no significant relationship between MFL and LR was rejected at 0.05 level of significant and the alternative hypothesis accepted.

\section{CONCLUSION}

The aimed of this study was to examine the relationship between Member Financial Literacy (MFL) and Loan Repayment (LR) in SACCOS. To achieve this aim, two specific objectives were addressed. The first specific objective was to assess MFL in SACCOS; it was concluded that MFL in SACCOS were low and that they were budgeting, savings, debt management and bookkeeping. Other MFL abilities were financial capability, awareness and goal. The MFL was very critical to LR; it affected financial behavior.

The second objective measured the influence of MFL and LR; the study concluded that there were a positive significant relationship between MFL and LR. The study partly confirmed the theory of planned behavior; financial attitudes, beliefs and perceived power shaped positive financial behavior increasing the chances of member LR. However, the theory of planned behavior were partly contradicted; in isolated cases, positive financial attitudes turned negative especially when members make overambitious loan demand leading to multiple borrowing increasing the risk of loan default. About budgeting, it placed a member in a better position to have self-control, patience and financial stability increasing member probability of LR. Savings play an important part on increasing members' opportunities for LR by having readily available money. Members that were having a saving culture were able to make timely LR compared to those that were not. Debt management and bookkeeping skills equally decreases the member possibilities of defaulting on LR, however, debt management skill predicted LR most compared to bookkeeping.

Provision of financial literacy education before giving out loans positively affected timely LR. Education on financial literacy skills was in most cases limited to only those offered by the auditors during Annual General Meetings (AGMs). Although this study focused on MFL, LR was an outcome of many other factors such as climate change, business failure, job loss, high interest rates, multiple borrowing, and misuse of borrowed loans, internal controls and loan policies. The low LR in SACCOS was a threat to SACCOS' survival. 
International Journal of Community and Cooperative Studies

Vol.8 No.1, pp.9-22, June 2020

Published by ECRTD- UK

ISSN 2057-2611(Print),

ISSN 2057-262X (Online)

\section{Recommendations}

The study recommends to SACCOS' managers and board to provide education on budgeting, savings, debt management, bookkeeping, financial capability, awareness and goal as topical issues to improve LR. The study also recommends to SACCOS' managers and board members to make it a requirement in SACCOS to provide education on financial literacy before taking a loan and after. Frequent reminders and penalties should be sent to those who failed to repay loans while rewards and recognition of efforts should be made for members making timely LR. More education on MFL should be directed to Rural SACCOS compared to Urban SACCOS.

\section{References}

Abiodun, A. E. and Harry, E. (2016). Financial literacy and SME firm performance. International Journal of Research Studies in Management. 5(1): 31-43

Ajzen, I. (2012). Theory of Planned Behavior. Handbook of theories of Social Psychology. Sage Publishers, USA. Pp23

Anania, P. and Rwekaza, G.C. (2018). Co-operative Education and Training as a means to improve performance in co-operative societies. Journal of social sciences. 1(2): 3950

Bee, K.F. (2014). Co-operative Education in Africa. Case of Moshi University College of Co-operatives and Business Studies, Tanzania. Asian Journal of Humanities and Social Studies. 2 (1): 166-178

Demertzis, M. and Batsakhan, U. (2018). Financial Literacy and Inclusive Growth in the European Union. Policy Contribution. 8(18): 1-18

Fernandes, D., Lynch, J. and Netemeyer R.G. (2014). Financial Literacy, Financial Education, an Downstream Financial Behaviors. Management Science. 60(8): 1861-1883

Flick, U. (2011). Introducing Research Methodology. Tj International limited. Britain. $271 \mathrm{pp}$.

Gathigia, R.M. (2011). The Role of Co-operative Education in the Performance of SACCO. A Case of

Nyeri District. Kenya. A Thesis for Award of MBA Degree at Kenyatta University: Kenya, $86 \mathrm{pp}$

Gibson, E. (2013). England. Co-operative Education- A Perspective from a Woodcraft Folk Volunteer. Journal of Co-operative Studies Volume. 46(2): 13-24

Hosmer D.W. and Lemeshow S.(2000). Applied Logistic Regression Second Edition John Wiley and Sons: Wiley- Inter Science Publication. New York, USA. 396pp

ILO, (2014). A Contribution of International Symposium on Co-operatives and Sustainable Development Goals. Berlin. Jurden Schwettmann. pp20.

Kenya Vision 2030 (2007). A globally Competitive and Prosperous Kenya. Pp180

Kenyan Co-operative Societies Act No. 490 of 2012. Republic of Kenya. 53pp.

Kinyuira, D. K. (2017). Assessing the Impact of Co-operative Education/Training on Cooperative

Performance. JSPM-Journal of Strategy and Performance Management. 5(1): 23-4 
International Journal of Community and Cooperative Studies

Vol.8 No.1, pp.9-22, June 2020

Published by ECRTD- UK

ISSN 2057-2611(Print),

ISSN 2057-262X (Online)

Klapper, L., Lusardi, A. and Van Oudheusden, P. (2015). Financial Literacy Around the World. In Standard \& Poor Ratings Services Global Financial Literacy Survey.(GLEC Working Paper)

Kobia, S. K. (2011). The Co-operative Movement in Kenya. Challenges and Opportunities.Colorscapes Media Ltd. Nairobi. 119pp.

Kumbhat, P. (2016). Learning Together? The Co-operative Union, the Workers Educational Association and the National Council of Labour College. Journal of Co-operative Studies.49 (2)5-20.

Lusardi, A. (2019). Financial Literacy and the Need for Financial Education: Evidence and Implications. Swiss Journal of Economics and Statistics. 155(1): 1-8

Lusardi, A. and Mitchell, O. S. (2014). The Economic Importance of Financial Literacy: Theory and Evidence: Journal of Economic Literature. 52(1): 5-44

Lusardi, A. and Tufano, P. (2015). Debt Literacy, Financial Literacy and Over indebtedness. Journal of Pension Economics and Finance. 14(4):332-368

Maskala, E., Omol, E., Wauyo, F. and Okumu, J. (2017). The role of Budgeting process in financial performance. A Case Study of Bugusu Co-operative Union ltd Mbale, Uganda. America Journal of Finance. 5(3) 31-48.

Miner, K. and Guiollotte, C. A. (2014). Relevance and Impact of Co-operative BusineEducation. 61pp.

Ministry of Industry Trade and Co-operative Development, MITCD, (2017). Report on Promoting Co- operative Enterprises for Industrializations. Government Printer. Nairobi. 52pp

Mmari, G. A. and Thinyane, L. C. (2019) Analysis of Factors Influencing Financial Performance Savings and Credit Co-operative Societies in Lesotho: Evidence From Maseru. International Journal of Financial Research. 10(2):121-136

Mugenda, O. and Mugenda, A. G.(2003). Research Methods. Quantitative and Qualitative Approaches (Revised Ed.). Nairobi. African Centre for Technology (ACTS).Pp384

Musabwasoni, G. Mulyungi, P. and Muganamfura, D (2018). Effects of Financial Literacy on

LoanRepayment Among Small and Medium Entrepreneurs of Microfinance Institutions Case Study of

Inozamihigo Umerengo SACCO in Nyaruguru District. IOSR Journal of Business and Management (IOSR- JBM). 5(4): 19- 37

Mutegi, H. K., Njeru, P. W. and Ongesa, N. T. (2015). Financial Literacy and Its Impact on Loan

Repayment by Small and Medium Entrepreneurs. International Journal of Economics,Commerce and Management United Kingdom. Retrieved from http://ijecm.co.uk/ ISSN 23480386.

Mwangi, D. K. and Ombui, K. (2018). Factors Affecting Financial Performance of Deposit Taking

SACCOS in Nairobi County, Kenya. International Journal of Scientific Research Publication. 8(10): 153-157

Ndiege, B. O., Mataba, L., Msonganzila, M. and Nzilano, L. K.(2016). The Link between Financial 
International Journal of Community and Cooperative Studies

Vol.8 No.1, pp.9-22, June 2020

Published by ECRTD- UK

ISSN 2057-2611(Print),

ISSN 2057-262X (Online)

Performance and Loan Repayment Management in Tanzanian SACCOS. African Journal of BusinessManagement. 10(4) 89-97

Ng'ondi, M. J. (2013). The contribution of SACCOS in improving social welfare in Iramba District. Evidence from Nyasamaja and Ukombozi SACCOS. A Dissertation submitted to Mzumbe University for Award of the degree of Master of Science in Entrepreneuship

Nyamboga, O. T., Nyamweya, B.O.,Abdi, A. M., Njeru, F. and Gongera, E. G (2014). An Assessment of Financial Literacy on Loan Repayment by Small and Medium Entrepreneurs in Ngara, Nairobi County. Research Journal of Finance and Accounting. ISSN 2222-2847. www.iiste.org

Rukwaru, M. (2015). Social Research Methods. Eureka Publishers. Meru, Kenya. 283ppSACCOS Societies Regulatory Authority, (2018). The SACCOS Supervision Annua Report. Pp139 pp

SASRA, ( 2018). The SACCO Supervision Annual Report. The SACCO Societies Regulatory Authority Nairobi, Kenya. Pp139

Singh, S. and Garg, N (2018). Financial Literacy among Youth. International Journal of Social Economics. ISSN:0306-8293. https;//www. emeraldisight.com.abs

Soni, A. K. and Saluja, H, P. S. (2016). Capacity Building. Arrangement of Co-operative Education and Training. International Journal of Human Resource and Research. 6 (1): 53-62.

TCDC, (2018). Tanzania Co-operative Development Commission. Field DatTehrani, R., Mehragan, M. R. \& Golkani, M.R. (2014). A Model for Evaluating Financial Performance of Companies by Data Development Analysis. A case Study of 36 Corporations affiliated with private organizations. International Business Research. $5(8): 8-16$

Thapa, K.B (2014). Status of Member Education and Training in the Co-operatives of Ilam.

Journal of Advanced Academic Research. Nepal. 1(1): 43-45

Wanjiku, K. J. and Muturi, W (2017). Effect of Financial Literacy on Loan RepaymentA

Case of Ecumenical Churches Loan Fund, Kenya. International Journal of Social

Science and Information Technology. Retrieved From http://www.ijssit.com.ISSN 2412-0294

World Bank (2018). Towards Financial Literacy in China. Models, Challenges and Global LessonWashington, Dc: The World Bank Group.

World Council of Credit Unions WOCCU (2017). The Global Network of CreditUnions and

Financial Cooperatives. Statistical Report.

Yeboah, E and Oduro, I. M (2018). Determinants of Loan Default in some Selected Credit

Unions in

Kumasi Metropolis of Ghana. Open Journal of Business and Management. 18 (6):778-795 